\title{
CAPITAL STRUCTURE AND MARKET POWER INTERACTION: EVIDENCE FROM MALAYSIA
}

\section{M. Pandey ${ }^{*}$}

\section{ABSTRACT}

This paper provides new insights on the way in which the capital structure and market power and capital serecture and profitability are related. We predict and show that capital structure and market power, as measured by Tobin's Q, have a cubic relationship. That is, at lower and higher ranges of Tobin's Q, firms employ higher debt, and reduce their debt at intermediate range. This is due to the complex interaction af the market conditions, agency problems and bankruptcy costs. We also show saucer-shaped relation between capital structure and profitability because of the interplay of agency costs, costs of external financing and debt tax shield. To our knowledge, we are the first to uncover these results.

Keywords: capital structure; market structure; market power; Tobin's Q; risk-shifting; moral hazard; agency problems; pecking order; trade-off theory; asset substitution.

\section{INTRODUCTION}

In corporate finance, the academic contribution of Modigliani and Miller $(1958 ; 1963)$ about capital structure irrelevance and tax shield advantage paved way for the development of alternative theories and a series of empirical research on capital structure. The alternative theories include the trade-off theory, the pecking order/asymmetric information theory and the agency theory. All these theories have been subjected to extensive empirical testing in the context of developed countries, particularly USA (see Harris and Reviv, 1991 for a review). A few studies report international comparison of capital structure determinants (Wald, 1999; Rajan and Zingales, 1995). There are some studies that provide evidence on the capital structure determinants from the emerging markets of South-east Asia (Pandey, 2001; Pandey et. al., 2000; Annuar and Shamsher, 1993; Ariff, 1998). The recent focus of corporate finance empirical literature has been to identify some "stylised" factors that determine capital structure.

There is relatively little evidence on the interaction between capital structure and product market structure. Some researchers have recently started looking at this interaction. Brander and Lewis (1986), Bolton and Scharfstein (1990), Maksimovic (1988) and Ravid (1988) offer theoretical framework for the linkage between capital structure and market structure. Harris and Raviv (1991) and Phillips (1995) provide 
surveys of the theoretical and empirical research on the relationship between capital structure and market structure. The studies in USA by Krishnaswamy, Mangla and Rathinasamy (1992), Chevalier (1993), and Phillips (1995) investigate the empirical relationship between capital structure and market structure. In a recent study, Rathinasamy, Krishnaswamy and Mantripragada (2000) examine this issue in international context using data from 47 countries. All these studies establish a linear relationship, either positive or negative, between capital structure and market structure. We argue in this paper that the relation between capital structure and market structure is cubic. We also show that the relation of profitability with capital structure is U-shaped or saucer-shaped. Results of our empirical work vindicate our predictions. To our knowledge, we are the first to uncover the cubic relation between capital structure and market structure and saucer-shaped relation between capital structure and profitability. Perhaps we are also the first to carry out the empirical work on the relationship between capital structure and market structure using data from the emerging Malaysian market.

The remaining sections of the paper are organized as follows: Section 2 presents a review of literature. Section 3 provides the theoretical framework. Section 4 describes data and research methodology. Section 5 reports results of the statistical analyses. Section 6 summarizes the main conclusions of the study.

\section{LITERATURE REVIEW}

Brander and Lewis (1986) and Maksimovic (1988) provide the theoretical framework that links capital structure and market structure. Contrary to the profit maximisation objective postulated in industrial organisation literature, these theories, like the corporate finance theory, assume that the firm's objective is to maximise the wealth of shareholders, and show that market structure affects capital structure by influencing the competitive behaviour and strategies of firms. Firms in the oligopolistic market will follow the strategy of maximising their output for improving profitability in favourable economic conditions (Brander and Lewis, 1986). In unfavourable economic conditions, they would take a cut in production and reduce their profitability. Shareholders enjoy increased wealth in good periods, but they tend to ignore decline in profitability in bad times as unfavourable consequences are passed on to lenders because of shareholders' limited liability status. Thus, the oligopoly firms, in contrast to firms in the competitive markets, would employ higher levels of debt to produce more when opportunities to earn higher profits arise. The implied prediction of the output maximisation hypothesis is that capital structure and market structure have a positive relationship.

In corporate finance, the agency costs theory supports the use of high debt, and it is consistent with the prediction of the output maximisation hypothesis. Jensen and Meckling (1977) argue that the share 
Geliliers-lenders conflict results into risk shifting from and wealth appropriation in favour of shareholders as they take on risky investment projects (asset substitution). Hence, shareholders and managers as their yents, are prompted to take on more borrowing to finance risky projects. Lenders would receive interest and principal if projects succeed, and shareholders would appropriate the residual income. However, Eenders would lose if project fails. It is difficult and costly for debt holders to be able to assess and monitor risky projects. Even debt covenants may not be able to protect them. In terms of the productmurket decisions, the implication of the agency theory is that firms would borrow more to pursue an angressive production policy that would benefit shareholders. Yet another corporate finance theory that unstifies the use of high debt is the tax-shield theory (Modigliani and Miller, 1963). Profitable firms burrow more to save taxes since interest costs are tax deductible. The output maximisation by oligopoly firms is supposed to increase their profitability. Hence, both the agency cost theory and the tax-shield theory would predict a positive relationship between capital structure and market structure.

Capital structure increases the chances of financial distress and bankruptcy. Firms face costs of financial fistress when they are unable to service debt. They will have high debt ratios if these costs are zero or rivial (Scott, 1976; Kim, 1978). Since costs of financial distress are non-trivial and high levered firm an actually go bankrupt, firms with high probability of bankruptcy will have low debt ratio. The chances af bankruptcy for firms with large reserve funds will be relatively less, but unlevered firms with high Jrofitability and large reserve funds would have great competitive advantage. These firms with "deep purse" may not only survive but they would also gain by driving their rival firms into bankruptcy Brander and Lewis, 1986; Bolton and Scharfstein, 1990). These firms follow a policy of aggressive production and predatory price cut to eliminate their rivals by forcing them into financial distress. Their strategy pays them off particularly when external funding is not available to firms of the target predatory grice behaviour. The implication of this model is that the unlevered firm with deep purses (high profitability and reserve funds) would have incentive to increase output to drive the competitors into bankruptcy. Empirically, we can predict a negative relationship between capital structure and market structure.

Myers (1977) provides a model under which debt causes under-investment (asset substitution). Firms reject those profitable, low risk investment projects that have the possibility of passing on benefits from shareholders to lenders. Further, internal financing is cheaper than external debt or equity financing due to asymmetric information. Higher debt makes higher output costly for a levered firm. In a competitive market, unlevered or low-levered rival firms will intensify competition by increasing their output and/or lowering prices. If the levered firms continue borrowing to meet the competition, they may face financial 
distress and bankruptcy. Hence, the pecking order/asymmetric information theory predicts a negative relation between capital structure and market power.

There are a few empirical studies that have investigated the issue of capital structure and market structure using data of the US firms. In these studies, market structure has been measured either in terms of price or quantity data or the Lerner index or the Herfindahl-Hirschman index or Tobin's Q. Krishnaswamy, Mangla and Rathinasamy (1992) find a positive relation between debt and market structure, measured by the Lerner index. Chevalier (1993) provides evidence in support of a negative relation between capital structure and market structure. This result is consistent with bankruptcy costs or the asymmetric information/pecking order hypotheses. Phillips (1995), using price and quantity data for market structure, finds a positive link between capital structure and market structure, consistent with the output and limited liability effect model. In a study of international firms from forty-nine countries, Rathnasamy, Krishnaswamy and Mantripragada (2000) also report a positive relation between capital structure, measured by total debt ratio and long-term ratio and market structure measured by Tobin's Q. Their finding supports the output and limited liability effect and agency theoretic risk-shifting model of capital structure and product market interaction. The results also provide support for the free cash flow model of Jensen (1986), in the form of positive relation between capital structure and profitability.

In empirical studies of determinants of capital structure, Q ratio has also been used as a proxy of future investment opportunities. These studies show mixed results. A number of studies confirm a negative relationship between Q ratio and debt ratio (Titman and Wessels, 1988; Barclay et. al., 1995; Lasfer, 1995; Rajan and Zingales, 1995; Barclay and Smith, 1996, while some find a positive relation (Michaelas et. al. 1999).

\section{THEORETICAL FRAMEWORK}

Capital structure could be defined in different ways. In the US, it is common to define capital structure in terms of long-term debt ratio. In a number of countries, particularly the emerging markets, companies employ both short-term and long-term debt for financing their assets, including current assets. It is also common for companies in developing countries to substitute short-term debt for long-term debt and roll over short-term debt. Hence, it is more appropriate and particularly in the context of developing economies, to define capital structure as total debt ratio. Rajan and Zingales (1995) argue that the definition of capital structure would depend on the objective of the analysis For example, for agency-problem related studies, capital structure maybe measured by total debt-to-firm value ratio. Debt could be divided into 
Hi curcus components, and numerator and denominator could be measured in book value and market In this study, we define our dependent variable - capital structure- as total debt-to-assets (ir ater-alo-capital employed); it is the most often used measure of capital structure in empirical studies. trat debe includes interest-bearing long-term and short-term debt. Assets include fixed assets and those minent assets that are financed by debt. In accounting sense this is equivalent to capital employed, mectauling shareholders' funds (equity) and short- and long-term debt.

We define market structure in terms of market power of firms. Market power means control of a firm see price or volume of production. In operational terms, market power implies a firm's monopoly, or Figupoly or competitive power. Rathnasamy, Krishnaswamy and Mantripragada (2000) state that market intuchure (power) could be measured by the Lerner index, or the Herfindahl-Hirschman index, or Tobin's (2. Lindenberg and Ross (1981) show that Tobin's Q (or simply Q) is theoretically a sound and practically he most powerful indicator of a firm's market power. In a competitive market, $Q$ of all firms will be andil to one. Firms with Q higher than one are expected to command competitive advantage either uligupoly or monopoly power. Hence, we define market power in terms of Q. There is also a practical meson for using this definition of market power. In developing countries, price and quantity or segmental turs are not available for measuring the Lerner index or the Herfindahl-Hirschman index.

The theoretical definition of Q is the ratio of market value of the firm to replacement cost of assets. It is nur easy to get replacement cost data in developing countries. Chung and Pruitt (1994) show that Q cuuld be effectively defined as the sum of market value of equity and book value of long-term debt and net current assets (current assets minus current liabilities) divided by the book value of equity, longterm debt and net current assets. Like Rathnasamy, Krishnaswamy and Mantripragada (2000), we have used this measurement in our study.

The empirical studies so far have predicted a linear relationship between capital structure and market power. We argue that this relationship could be a cubic relationship. Our arguments are as follows. A firm in oligopoly condition sustains its aggressive production and high-income strategy by employing higher level of debt. Shareholders of the firm gain in terms of increased wealth. In adverse market conditions, the limited liability provides protection to shareholders against the risky production decision and lenders would suffer. Thus, a firm's debt level will increase as it gains market power reflected in Q. On the other hand, as debt increases, there are significant costs in terms of increased probability of bankruptcy and financial distress. This cost would be accentuated by the behaviour of no or low-debt 
firms with "deep purses". They would resort to predatory price behaviour and lead their rivals to bankruptcy. This argument suggests a negative relationship between capital structure and $Q$. These two opposing effects point to the possibility of a non-linear relationship between capital structure and market power. As a firm starts gaining market dominance, it will increase debt to increase its production and income. That is, as firms' market power increases, they employ more debt to pursue their output maximisation strategy. This attracts rival firms to intensify competition by cutting price and/or output. At the intermediate level of market dominance when competition intensifies through price cut, higher costs of debt squeezes profitability of highly levered firms and their chances of financial distress and bankruptcy increase. Levered firms react by reducing debt or increase production through improved assets utilisation. However, after consolidating their position, firms at higher level of market dominance once again leverage the use of debt in expanding their production. Firms with strong profitability and reserve funds and high market dominance adopt high-risk production strategy and use more debt. Thus, we can predict a cubic relationship between capital structure and market power. As shown in Figure 1, firms at relatively lower and higher levels of market power employ more debt, while firms at intermediate level of market dominance are vulnerable to rivals' competitive threat and reduce their debt.

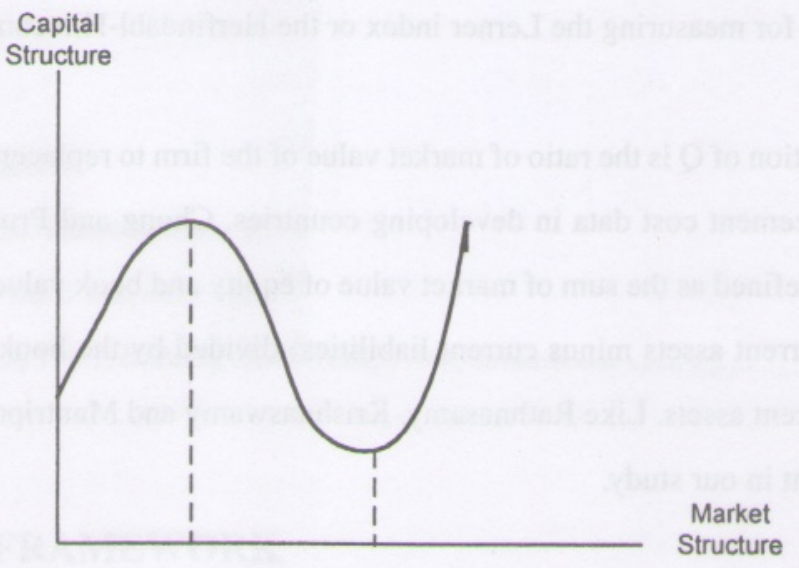

Figure 1: Capital and Market Structure

Empirical literature on capital structure finds many variables as its determinants. For example, in a comprehensive comparative cross-country study, Rajan and Zingles (1995) find growth, tangibility (fixed assets to total assets ratio), profitability and size as important determinants of capital structure. Many other studies (Titman and Wessels, 1988; Pandey, 2001; Pandey et. al. 2000; Barclay and Smith, 1996; Castanias, 1983; Bradley, Janell and Kim, 1984) also show risk and investment opportunity as important determinants of debt policy. 
is an important independent variable that has an influence on capital structure. As per the information hypothesis of Myers (1977) and Myers and Majluf (1984), firms, irrespective cet power, would depend on internally generated funds for their expansion since external higher costs. This suggests a negative relationship between capital structure and profitability, wnit masils of empirical studies support it ((Kester, 1986; Friend and Lang, 1988; Titman and Wessels, Zujan and Zingales, 1995; Michaelas et. al., 1999). But the alternative interest-tax shield hypothesis -Miller, 1963) predicts a positive relationship between capital structure and profitability. 1986) and Williamson (1988) consider debt as a disciplining mechanism to ensure that managers profits rather than building their personal empires. In the Jensen model, firms with free cash gh profitability, will have higher debt. Thus, we predict that more profitable firms will employ Jebt and will implement high output strategy. Given these conflicting hypotheses, it is plausible fict a non-linear relationship between capital structure and profitability. Firms at lower levels of -ility would employ more internal funds since external funds are expensive and non-debt tax (such as depreciation) may be more than enough to take advantage of tax benefits (DeAngelo lasulis, 1980). At higher level of profitability, firms have more profits to shield from taxes as well ay are able to generate more output by employing assets effectively. These firms employ more debt. S. it is plausible to predict a quadratic - U-shaped- relationship between capital structure and mability. In fact, the relationship, as shown in Figure 2, may be saucer-shaped. There may be some range of profitability were firms may not have enough incentive to increase or reduce debt.

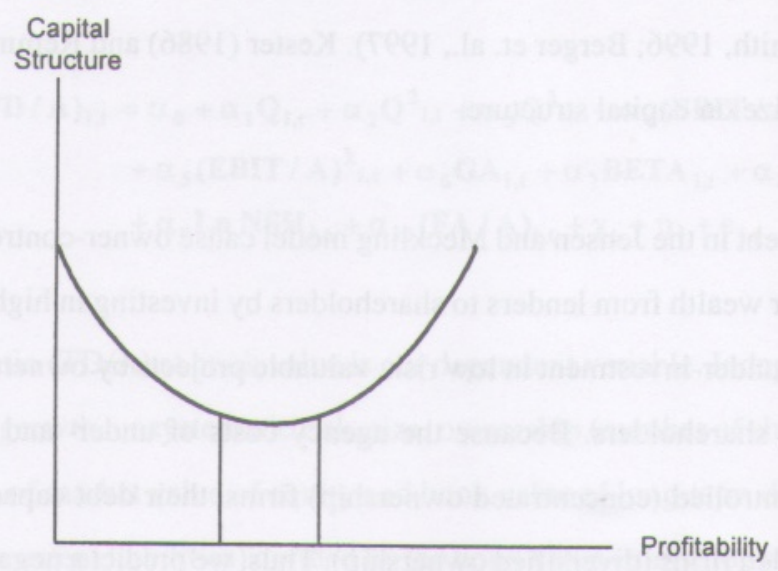

Figure 2: Capital Structure and Profitability According to Myers (1977) the firm's future growth opportunities represent call options. High growth firms may hold more options for future investments, and as such these firms avoid issuing debt. They 
would like to issue equity when it is necessary in some future date to exercise an option. Outstanding debt in such eventuality would transfer wealth from shareholders to lenders. According to Myers' option model and the pecking order hypothesis of Myers and Majluf (1984), firms with high growth should use less debt. The trade-off theory also arrives at a similar prediction. In the event of bankruptcy caused by higher debt, the value of growth opportunities will disappear. Thus, firms with high growth opportunities are susceptible for larger bankruptcy costs, leading them towards low debt.

Myers (1984) points out the lack of sufficient evidence on the relationship between capital structure and risk. According to the trade-off theory, higher debt ratio increases the probability of financial distress. With positive financial distress/bankruptcy costs, the risk affects a firm's debt ratio. Ross (1985) demonstrates a theoretical inverse relation between cash flow beta and financial leverage. A theoretically and empirically sound measurement of risk is the firm's unlevered beta. Chung (1989) shows that the relationship between capital structure and the unlevered beta is negative. Thus, we can predict a negative relationship between leverage and risk. However, it is shown that for a negative relationship between risk and leverage, bankruptcy costs should be quite large (Castanias, 1983; Bradley, Janell and Kim, 1984).

Large firms are likely to be more diversified and less prone to bankruptcy (Rajan and Zingales, 1995). They are also expected to incur lower direct costs in issuing debt. Thus, large firms are expected to employ higher amount of debt than small firms. The empirical evidence is mixed. A large number of studies find a significant positive relation between size and debt ratio (Lasfer, 1995; Rajan and Zingales, 1995; Barclay and Smith, 1996; Berger et. al., 1997). Kester (1986) and Remmers et. al. (1974) find no significant effect of size on capital structure.

The agency costs of debt in the Jensen and Meckling model cause owner-controlled firms (concentrated ownership) to transfer wealth from lenders to shareholders by investing in high-risk projects. Similarly, Myers (1977) argues under-investment in low risk, valuable projects by owners to avoid wealth transfer from debt holders to shareholders. Because the agency costs of under- and over-investment will be higher for owners-controlled (concentrated ownership) firms, their debt capacity would be lower than the managers-controlled firms (diversified ownership). Thus, we predict a negative relationship between ownership and debt ratio.

According to trade-off hypothesis, tangible assets act as collateral and provide security to lenders in the event of financial distress. Collaterality also protects lenders from moral hazard problem caused by the 
Enarehriliters-lenders conflict (Jensen and Meckling, 1976). Thus, firms with higher tangible assets are nened to have high level of debt. As regards the empirical evidence, some studies report a significant Ce relationship between tangibility and total debt (Titman and Wessels, 1988; Rajan and Zingales,

\section{DATA AND METHODOLOGY}

The use data of companies listed on the Kuala Lumper Stock Exchange for the period from 1993 to בnive Our analysis covers data from 1994 to 2000 as data for year 1993 are used to calculate some sor 1994. Companies with missing data are excluded from the study. We also exclude the and securities sector companies as their financial characteristics and use of leverage is different from other companies. We also drop companies with zero sales and negative Aurter eliminating outliers, sample size is 208 companies for each period. We adjust data of those mancanies, which change their financial year. Such changes result in one year with missing data and the chequent year data of more than 12 months. We first annualise the subsequent year data, and then whissitute missing data by the mean value.

Our estimation model uses panel data. Panel data, unlike cross-section data, allows controlling for uncbservable heterogeneity through individual (firm) effect $\left(\eta_{i}\right)$. We also include dummies for time wariable to measure temporal effect $\left(\gamma_{1}\right)$. This helps in controlling the effect of macro-economic variables an capital structure. Thus, we use a two-way fixed effect model as follows:

$$
\begin{aligned}
& (\text { TD } / \mathbf{A})_{\mathrm{i}, \mathrm{t}}=\alpha_{0}+\alpha_{1} \mathbf{Q}_{\mathrm{i}, \mathrm{t}}+\alpha_{2} \mathbf{Q}_{\mathrm{i}, \mathrm{t}}+\alpha_{3} \mathbf{Q}^{3} \mathrm{i}_{\mathrm{t}}+\alpha_{4}(\mathrm{EBIT} / \mathrm{A})_{\mathrm{i}, \mathrm{t}} \\
& +\alpha_{5}(\text { EBIT } / A)^{2} i, t+\alpha_{6} \text { GA }_{i, t}+\alpha_{7} \text { BETA }_{i, t}+\alpha_{8} \operatorname{Ln} A_{i, t} \\
& +\alpha_{9} \operatorname{LnNSH}_{\mathrm{i}, \mathrm{t}}+\alpha_{10}(\mathbf{F A} / \mathbf{A})_{\mathrm{i}, \mathrm{t}}+\gamma_{\mathrm{t}}+\eta_{\mathrm{i}}+\varepsilon_{\mathrm{i}, \mathrm{t}}
\end{aligned}
$$

Total debt-to-asset ratio (TD/A) at book value is our dependent variable. Independent variables include Q ratio, profitability, growth, unsystematic risk, size, ownership (number of shares) and tangibility. Q is calculated as the sum of market value of equity and book value of long-term debt and net current assets (current assets minus current liabilities) divided by the book value equity, long-term debt and net current assets. Growth (GA) is measured as one plus annual change in assets. Profitability is defined as earnings before interest and taxes divided by assets or capital (EBIT/A). Risk is defined as systematic risk, and it is measured by unlevered beta. Beta for each firm is calculated using the weekly share price data. The calculated beta for each company is unlevered for its level of leverage. Size is measured as natural log 
of assets. Ownership is measured by natural log of number of outstanding shares. It is assumed that larger number of shares imply diffused ownership. Tangibility is defined as fixed assets divided by assets.

\section{RESULTS}

Table 1 provides means and standard deviations of the dependent and independent variables for each year from 1994 to 2000 and for the period 1994-00. The average total debt ratio (TDR) for the period of $1994-00$ is $30 \%$. However, TDR has been steadily increasing over years, ranging from $24 \%$ to $35 \%$ in 2000. Q ratio has shown fluctuations during 1994-00. It was lower in 1997 and 1998, corresponding with the financial and stock market crisis in Malaysia. Assets growth was quite high for the years from 1994 to 1996; but it showed a sharp decline in the last three years. Profitability also declined significantly in the last three years, that is, crisis and post crisis period.

Table 2 provides correlation matrix for the pooled sample of 1456 firms/years observations'. We find that size $(\ln \mathrm{A})$ and $\mathrm{Q}$ ratio have a significant positive relationship with total debt ratio while risk (unlevered beta) and profitability (EBIT/A) have a significant negative relationship. Other significant relationships exit between risk and size and size and ownership ( $\ln \mathrm{NSH})$. The negative relationship between risk and size implies that the large firms, being more diversified, have lower systematic risk. The positive relationship between size and ownership indicates that the large-sized Malaysian firms have more diffused ownership.

Table 3, column two, presents results of two-way fixed firm and time effects model. Our main concern is to test the specification about the relationship between capital structure (total debt ratio) and market power ( $Q$ ratio). As predicted, we find that the coefficients of variables $Q$ and $Q^{3}$ are positive and the coefficient of $Q^{2}$ is negative. All these coefficients are significant at $1 \%$ level of significance, which supports a cubic specification for the capital structure-market power relationship for Malaysian firms. We interpret this evidence as consistent with the economic theory of output maximisation and finance theories of agency costs and bankruptcy costs. For a given initial range of $\mathrm{Q}$ ratio, any increase in this ratio leads firms to increase output and take more risk to maximise shareholders wealth. This causes rivalry in the market and competition intensifies, particularly from unlevered firms. The fear of bankruptcy and loss of investment and profitability obliges levered firms to reduce debt. Hence, for some intermediate

\footnotetext{
Correlation coefficients are based on pooled OLS without controlling for individual firms and time effects.
} 
any of Q, the competition forces levered firms to lessen debt. Finally, for well-established, profitable firms with very high Q ratio and low probability of financial distress and bankruptcy, the output masuimisation seems to dominate the relation between capital structure and Q ratio.

We also find expected signs of the coefficients of profitability variables, EBIT/A, (EBIT/A) ${ }^{2}$ and (EBIT/ 4.7. The coefficients of EBIT/A and (EBIT/A) ${ }^{3}$ are, respectively, negative and positive and statistically significant at $1 \%$ level of significance. The coefficient of (EBIT/A) $)^{2}$ is not statistically different from Thus, our results confirm a saucer-shaped relationship between debt ratio and profitability. We merpret this evidence as a trade-off between the effects of asymmetric information, agency costs and as benefits. For a given initial range of profitability, any increase in this ratio leads firms to internally finance its output growth and minimise cost of financing. It is also likely that at relatively lower levels af profitability, firms may not have much incentive to issue debt, as other non-debt tax shields may be axallable to them. There may also exit an intermediate range of profitability where firms do not have sufficient incentive either to increase or decrease debt any further. Finally, at higher levels of profitability and given their market power and intensifying competition, firms will increase borrowing to expand their output. Also, they have more profits to shield from taxes. Further, agency costs will be higher once firms reach high levels of profitability.

The coefficients of other control variables are also statistically significant. Consistent with option model of Myers (1977) and the pecking order hypothesis of Myers and Majluf (1984), our results show a significant negative relation between growth and debt ratio. We also find a negative relationship between (systematic) risk and debt ratio. This finding is consistent with the trade-off theory. The positive relation between size and debt ratio is evidence in favour of the hypotheses that larger firms tend to be more diversified and less prone to bankruptcy and the transaction costs of issuing debt is smaller. The negative relation between debt ratio and the size of shareholding means that more diffused ownership results in lower leverage. The result supports the agency hypothesis. Our results indicate a significant positive relation of tangibility (FA/A ratio) with debt ratio. These results vindicate the trade-off theory that postulates a positive correlation between debt ratio and tangibility since fixed assets act as collateral in debt issues.

In Table 3 we also present the results of fixed firm effects models (without the time effect). Column three gives results of fixed effect model with standard and White's heteroscedasticity-consistent t-values. The results of this model are similar to the two-way fixed (firm and time) model and for all variables 
White's heteroscedasticity-consistent t-values are significant at $1 \%$ level of significance. In column four, we provide autocorrelation corrected results of fixed effect model. We do notice that due to autocorrelation, the estimates of variables change but our basic conclusions about the effects the variable $\mathrm{Q}$ and other variables remain as predicted and generally consistent with the fixed firm and time effect model. The estimated Hausman statistics (H-stat.) show that fixed effect models are to be preferred over random effects model.

\section{CONCLUSION}

This study empirically examines the relationship between capital structure and market power using data for 208 Malaysian companies for the period from 1994 to 2000 . The estimation method uses fixed firm and time effects model on panel data. The study provides new insights on the way in which the capital structure measured by total debt-to-assets ratio and market power measured by Tobin's $Q$ ratio are related. We predict and show that capital structure and market power have a cubic relationship. That is, at lower and higher ranges of Tobin's Q, firms employ higher debt, and reduce their debt at intermediate range. This is due to the complex interaction of market conditions, agency costs, and bankruptcy costs. We also show saucer-shaped relation between capital structure and profitability because of the interplay of agency costs, costs of external financing and interest tax-shield. In addition to $Q$ ratio and profitability, we include other independent variables in our estimation. We find that size and tangibility have a positive and growth, risk (systematic) and ownership have a negative influence on capital structure. 
M.N. and Shamsher, M. (1993). Capital Structure, Capital Market Review, 1(2), 171-177.

unfif (1998). Stock Pricing in Malaysia - Corporate Financial \& Investment Management. UPM

Furcliry, M. J. and Smith, C. W. (1996). On Financial Architecture: Leverage, Maturity and Priority, thurnal of applied Corporate Finance, 8, 4, 4-17.

Aurclyy, M. J. and Smith, C. W. (1999). The Capital Structure Puzzle: Another Look at the Evidence, of Applied Corporate Finance, 12(1), 8-20.

Farclay, M. J., Smith, C. W., and Watts, R. L. (1995). The Determinants of Corporate Leverage and Druisend Policies, Journal of Applied Corporate Finance, 7(4), 4-19.

Berger, P. G., Ofek, E. and Yermack, D. L. (1997). Managerial Entrenchment and Capital Structure Decisions, Journal of Finance, 52, 4, 1411-1438.

Balhon, P. and Scharfstein, D. (990). A Theory of Production based Agency Problems in Financial Contracting, American Economic Review, 80 (1), 59-581.

Bradley, M., Jarrell, G. A. and Kim, E. H. (1984). On the Existence of Optimal Capital Structure Theory and Evidence, Journal of Finance, 39 (July), 857-878.

Brander, J. A. and Lewis, T. R. (1986). Oligopoly and Financial Structure: The Limited Liability Effect, American Economic Review, 76 (5), 956-970.

Castanias, R. (1983). Bankruptcy Risk and Optimal Capital Structure, Journal of Finance, 1617-1635.

Chevalier, J. A. (1993). Capital Structure and Product-market Competition: Empirical Evidence from the Supermarket Industry, American Economic Review, 85(3), 415-435. 
Chung, K. (1989). Debt and Risk: A Technical Note, Journal of Business Finance \& Accounting, Winter, 719-727.

Chung, K. and Pruitt, S. W. (1994). A Simple Approximation of Tobin's Q, Financial Management, 23 (3), 70-74.

Chung, K. H. (1993). Asset Characteristics and Corporate Debt Policy: An Empirical Test, Journal of Business Finance and Accounting, 20(1), 83-98.

Crutchley, C. E. and Hansen, R. S. (1989). A Test of the Agency Theory of Managerial Ownership, Corporate Leverage, and Corporate Dividend, Financial Management, 18(4), 36-46.

DeAngelo, H. and Masulis, R.W. (1980). Optimal Capital Structure Under Corporate and Personal Taxation, Journal of Financial Economics, 8(1), 3-29.

Ferri, Micheal G. and Jones, Wesley H. (1979). Determinants of Financial Structure: a New Methodological Approach, The Journal of Finance, 34(3), 631-644.

Friend, I. and Lang, L. H. P. (1988). An Empirical Test of the Impact of Managerial Self-interest on Corporate Capital Structure, Journal of Finance, 43, 271-281.

Harris, M. and Raviv, A. (1991). The Theory of Capital Structure, Journal of Finance, XLVL(1), 297-355.

Jensen, M.C. and Meckling, W.H. (1976). Theory of the Firm: Managerial Behavior, Agency Costs and Capital Structure, Journal of Financial Economics, 3, 11-25.

Kester, C. W. (1996). Capital and Ownership Structure: A Comparison of United States and Japanese Manufacturing Corporations, Financial Management, 5-16.

Kim, E. H. (1978). A Mean-variance Theory of Optimal Capital Structure and Corporate Debt Capacity, Journal of Finance, 33, 45-63. 
, C. R., Mangla, I. and Rathinasamy, R. S. (1992). An Empirical Analysis of the Relationship Financial Structure and Market Structure, Journal of Financial and Strategic Decisions, $75-88$.

Lafier, M. A. (1995). Agency Costs, Taxes and Debt: The U. K. Evidence, European Financial Nilungement, 1, 3, 265-285.

Lundenberg, E. B. and Ross, S. A. (1981). Tobin's Q Ratio and Industrial Organization, Journal of Plusiness, 54 (1), 1-32.

MGaksaimovic, V. (1988), Capital Structure in Repeated Oligopoly, Rand Journal of Economics, 19, 3907.

Mafichaelas, N., Chittenden, F. and Poutziouris, P. (1999). Financial Policy and Capital Structure Choice in U. K. SMEs: Empirical Evidence from Company Panel Data, Small Business Economics, 12, $113-130$.

Mbodigliani, F. and Miller, M. H. (1958). The Cost of Capital, Corporation Finance and The Theory of Investment, American Economic Review, XLVIII(3), 261-297.

Modigliani, F. and Miller, M. H. (1963). Corporate Income Taxes and the Cost of Capital: A Correction, American Economic Review, 53(3), 433-443.

Myers, S. C. (1977). Determinants of Corporate Borrowing, Journal of Financial Economics, 5, 147-175.

Myers, S. C. (1984). The Capital Structure Puzzle, The Journal of Finance, XXXIX(3), 575-592.

Myers, S. C. and Majluf, N. S. (1984). Corporate Financing and Investment Decisions When Firms Have Information that Investors Do not Have, The Journal of Financial Economics, 13, 187-221.

Pandey, I. M. (2001). Capital Structure and the Firm Characteristics: Evidence from an Emerging Market, Working Paper: 2001-10-04, Indian Institute of Management, Ahmedabad, India. 
Pandey, I.M., Chotigeat, T. and Ranjit, M. K. (2000). Capital Structure Choices in an Emerging Capital Market: Case of Thailand, Management and Change, 4, 1, 1-14.

Phillips, G. M. (1995). Increased Debt and Industry Markets: An Empirical Analysis, Journal of Financial Economics, 37 (2), 189-238.

Phillips, G. M. (1992). Financial Slack, Refinancing Decisions and Firm Competition, Working Paper, Purdue University, West Lafayette, IN.

Rajan, R. G. and Zingales, Luigi (1995). What Do We Know about Capital Structure? Some Evidence from International Data, Journal of Finance, 50, 5, 1421-1460.

Rathinasamy, R. S., Krishnaswamy, C. R. and Mantripragada, K. G. (2000), Capital Structure and Product Market Interaction: An International Perspective, Global Business and Finance Review, 5 (2), 51-63.

Ravid, S. A. (1988). On the Interactions between Production and Financial Decisions, Financial Management, 17 (3), 87-99.

Remmers, L., Stonehill, A., Wright, R. and Beekhuisen, T. (1974). Industry and Size as Debt Ratio Determinants in Manufacturing Internationally, Financial Management (Summer), 24-32.

Ross, S. (1985). Debt and Taxes and Uncertainty, Journal of Finance, July, 637-657.

Scott, J. H. (1976). A Theory of Optimal Capital Structure, Bell Journal of Economics, 7, 33-54.

Titman, S. and Wessels, R. (1988). The Determinants of Capital Structure Choice, The Journal of Finance, XLIII, 1, 1-19.

Wald, John K. (1999). How Firm Characteristics Affect Capital Structure: An International Comparison, Journal of Financial Research, 22(2), 161-187.

Williamson, O. E. (1988). Corporate Finance and Corporate Governance, Journal of Finance, 43, $567-591$. 
Table 1: Summary Statistics

\begin{tabular}{|c|c|c|c|c|c|c|c|c|c|}
\hline & & 1994 & 1995 & 1996 & 1997 & 1998 & 1999 & 2000 & $1994-00$ \\
\hline \multirow[t]{2}{*}{ Tue } & Mean & 0.2472 & 0.2590 & 0.2815 & 0.3181 & 0.3493 & 0.3384 & 0.3234 & 0.3024 \\
\hline & Stdev. & 0.1955 & 0.2101 & 0.2122 & 0.2268 & 0.2454 & 0.2591 & 0.2623 & 0.2339 \\
\hline \multirow[t]{2}{*}{ a } & Mean & 3.6590 & 2.9739 & 3.3597 & 1.7492 & 1.9531 & 2.5186 & 2.2304 & 2.6348 \\
\hline & Stdev. & 3.1742 & 1.8647 & 2.0160 & 1.8946 & 1.7683 & 3.6665 & 3.7663 & 2.7996 \\
\hline \multirow[t]{2}{*}{ EITIA } & Mean & 0.1417 & 0.1331 & 0.1245 & 0.0990 & 0.0483 & 0.0564 & 0.0572 & 0.0943 \\
\hline & Stdev. & 0.1361 & 0.1000 & 0.0987 & 0.0991 & 0.1201 & 0.1144 & 0.0871 & 0.1149 \\
\hline \multirow[t]{2}{*}{ si. } & Mean & 0.3191 & 0.4010 & 0.4713 & 0.3006 & 0.0870 & 0.0259 & 0.0410 & 0.2351 \\
\hline & Stdev. & 0.6643 & 0.7152 & 1.1802 & 0.5289 & 0.2401 & 0.3729 & 0.3422 & 0.6682 \\
\hline \multirow[t]{2}{*}{ Eeta } & Mean & 0.9938 & 0.8881 & 1.0794 & 0.6194 & 0.6302 & 0.7053 & 0.5579 & 0.7820 \\
\hline & Stdev. & 0.3799 & 0.4004 & 0.5686 & 0.3205 & 0.3351 & 0.3579 & 0.3220 & 0.4344 \\
\hline \multirow[t]{2}{*}{ LxA } & Mean & 5.4800 & 5.5936 & 5.7111 & 5.8052 & 5.8314 & 5.8300 & 5.8308 & 5.7260 \\
\hline & Stdev. & 0.5138 & 0.5198 & 0.5201 & 0.5275 & 0.5461 & 0.5309 & 0.5407 & 0.5431 \\
\hline \multirow[t]{2}{*}{ LN NSH } & Mean & 11.7331 & 11.8938 & 12.0167 & 12.1065 & 12.1454 & 12.1686 & 12.2373 & 12.0430 \\
\hline & Stdev. & 1.1291 & 1.1231 & 1.1083 & 1.1126 & 1.1130 & 1.0973 & 1.0840 & 1.1194 \\
\hline \multirow[t]{2}{*}{ FALA } & Mean & 0.4989 & 0.4777 & 0.4646 & 0.4502 & 0.4599 & 0.4695 & 0.4873 & 0.4726 \\
\hline & Stdev. & 0.2875 & 0.2952 & 0.2923 & 0.2772 & 0.2849 & 0.2956 & 0.3753 & 0.3025 \\
\hline
\end{tabular}

Table 2: Correlation Matrix (1456 Firms/Years Pooled Observations)

\begin{tabular}{|l|l|l|l|l|l|l|l|l|}
\hline & TDR & Q & EBITA & GA & BETA & Ln A & Ln NSH & FA/A \\
\hline TDR & 1.0000 & & & & & & & \\
\hline Q & 0.3552 & 1.0000 & & & & & & \\
\hline GAT/A & -0.3284 & 0.0895 & 1.0000 & & & & & \\
\hline BETA & -0.3284 & -0.0411 & 0.0575 & 1.0000 & & & & \\
\hline LaA A & -0.3284 & 0.0266 & 0.0575 & 0.0034 & 1.0000 & & & \\
\hline La NSH & 0.0867 & -0.0457 & -0.0343 & 0.0255 & -0.3609 & 1.0000 & & \\
\hline FAA & -0.0570 & -0.0498 & -0.0071 & -0.0473 & -0.1423 & 0.8716 & 1.0000 & \\
\hline
\end{tabular}




\section{Dependent Variable: TDR}

\section{Table 3: Results of Fixed Effects Models}

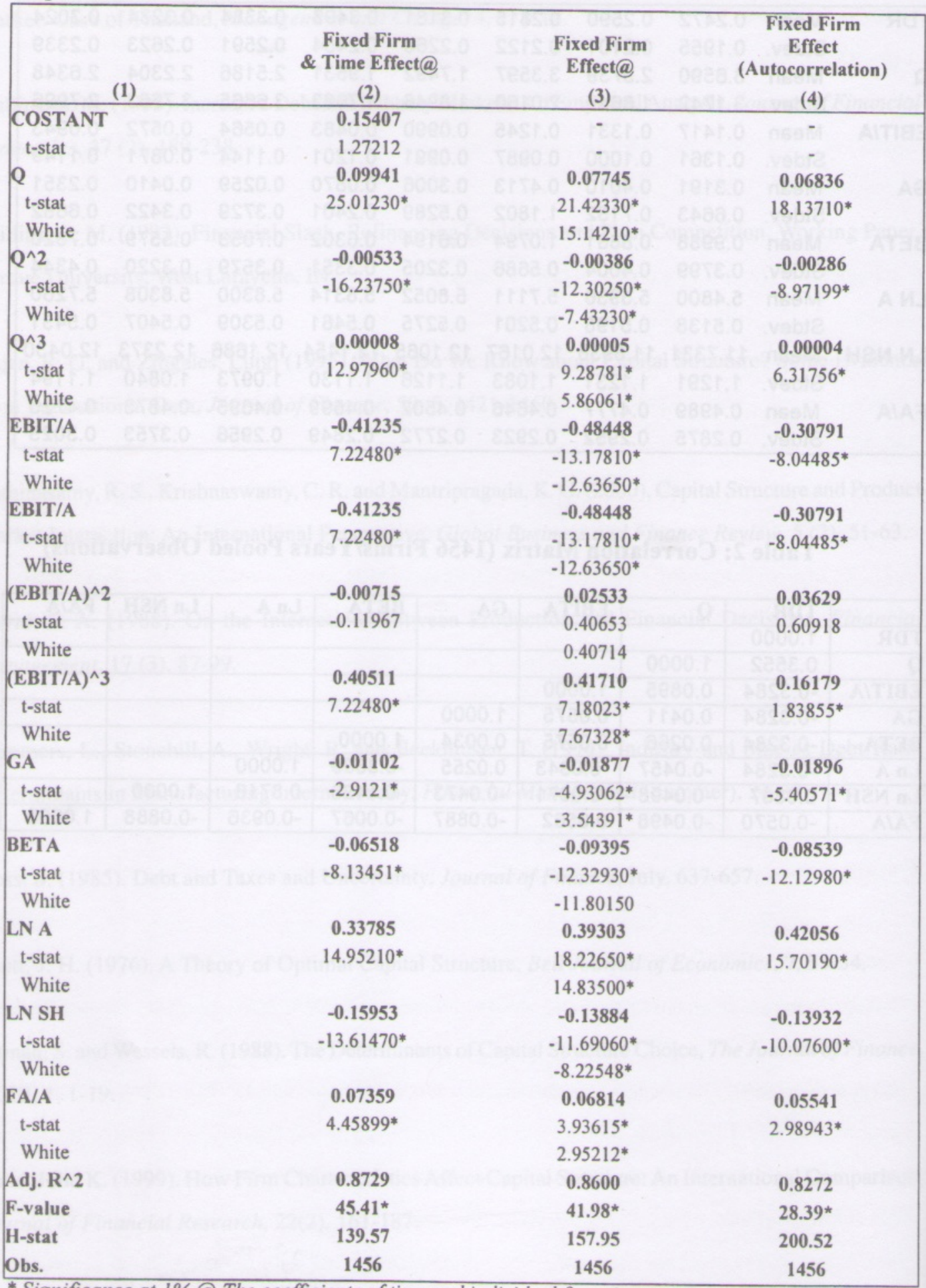

*Significance at 1\% @ The coefficients of time and individual firms intercepts are not reported. 